\title{
Breach of Contact: An Intercultural Reading of China Miéville's The City and The City
}

\author{
Peter Cowley and Barbara Hanna, University of Queensland
}

When I was fourteen I saw the Breach for the first time. The cause was the most common of all such - a traffic accident. A boxy little Ul Qoman van ... had skidded. It had been traveling a crosshatched road, and a good third of the cars in that area were Besź.

... The van driver ... ground diagonally across the tarmac ... and thudded into the wall of a Besź boutique and the pedestrian window-shopping there. The Besź man died; the Ul Qoman driver was badly hurt ...

In seconds, the Breach came. Shapes, figures, some of whom perhaps had been there but who nonetheless seemed to coalesce from spaces between smoke from the accident, moving too fast it seemed to be clearly seen, moving with authority and power so absolute that within seconds they had controlled, contained, the area of the intrusion. The powers were almost impossible, seemed almost impossible, to make out. At the edges of the crisis zone the Besź and, I could not fail to see,

U1 Qoman police were pushing away the curious in their own cities, taping off the area, closing out outsiders, sealing off a zone inside of which, their quick actions still visible though child-me so afraid to see them, Breach, organizing, cauterizing, restoring.

China Miéville, The City and The City (2009: 79-81).

\section{Introduction}

In the city of Besźel, in which China Miéville's police procedural novel The City and

The City is largely set, two minority communities have found a distinctive modus of cooperation:

A common form of establishment, for much of Besźel's history, had been the DöplirCaffé: one Muslim and one Jewish coffeehouse, rented side by side, each with its own counter and kitchen, halal and kosher, sharing a single name, sign and sprawl of tables, the dividing wall removed. Mixed groups would come, greet the two proprietors, sit together, separating on communitarian lines only long enough to order their permitted food from the relevant side, or ostentatiously from

PORTAL Journal of Multidisciplinary International Studies, vol. 11, no. 2, July 2014.

(C) 2014 [Peter Cowley and Barbara Hanna]. http://dx.doi.org/10.5130/portal.v11i2.3204

This is an Open Access article distributed under the terms of the Creative Commons Attribution 4.0 Unported (CC BY 4.0) License (https://creativecommons.org/licenses/by/4.0/), allowing third parties to copy and redistribute the material in any medium or format and to remix, transform, and build upon the material for any purpose, even commercially, provided the original work is properly cited and states its license. 
either and both in the case of freethinkers. Whether the DöplirCaffé was one establishment or two depended on who was asking: to a property tax collector it was always one. (26)

In this passage, the evocation of different religious communities cohabiting a single - or doubled - urban space draws on our familiarity with certain fractured cities (Belfast, Jerusalem, Warsaw). But let there be no misunderstanding: it is not religious or racial division that explains the title of the novel. ${ }^{1}$ The multiplicity and recombination foregrounded in this excerpt, with their attendant assumptions of cultural hybridity and flexibility, are only part of the story of plurality modelled by Miéville through the DöplirCaffé. If we choose to start here, it is because this passage's description of the caffé 's organization - and the ways in which it is used, and above all the way in which it can be described - helpfully sets the agenda for our reading of Miéville's novel, which takes as its primary concern the management of intercultural relationships. The City and The City is premised on a unique instantiation of the management of cultural difference, and is haunted by the correlative question: one city or two? In the case of a DöplirCaffé, therefore, what strikes us is the fact that the answer to the question 'one establishment or two?' depends on who is asking. Taking the interpretative flexibility of the caffé as a model for how we might read the novel itself, we underline the issue of genre, not as a formal property, but as an interpretive move: whether the city and the city of the title, Besźel and its neighbour Ul Qoma, are one city or two, depends on the expectations, generic and disciplinary, brought to the story.

It is our contention that intercultural theory offers a framework for a reading of The City and The City that provides an alternative to the dominant current of critical uptakes. Insisting on the separation of the cities, rather than the desirability of their (re)unification, our reading privileges intercultural agency and border crossing over the panacea of unity and the utopia of razed boundaries. The aim of this article, then, is twofold. While our reading, taking traction from the perspective of cultural encounter, demonstrates that cross-cultural pragmatics can be brought to bear on the interpretation of literature, it further ponders whether this tale of interculturality denied contains lessons for the conceptualisation and therefore practice of intercultural competence and training.

\footnotetext{
${ }^{1}$ Yet while these are not the primary cause of fracture between the cities, racial and religious divides have not been overcome; rather, they are merely relegated to the background.
} 


\section{Cleavage: One city or two?}

Naturally, the title of the novel mobilises readerly expectations of some form of doubling — doppelgängers, twins, ghosts and reflections might come to mind — and therefore of possible relations between the doubles; also, of possible causes of the doubling. Fission or fusion? For 1,700 or perhaps 2,000 years, a city, and possibly its neighbour, have stood on the same site in Eastern Europe (51). Perhaps two cities met; or perhaps one city split. In the absence of an authoritative historical narrative this moment is referred to in the novel by the term 'Cleavage,' which in turn presents the conundrum: Did two cities cleave together or was one cloven asunder?

Whatever their origin(s), today the cities house two culturally distinct city-states. The table below presents what are understood by their inhabitants to be signifiers of cultural difference and therefore, additionally, of status as a culture.

\begin{tabular}{|c|c|c|}
\hline & Besźel & UI Qoma \\
\hline Beverage of choice & Coffee & Tea \\
\hline Currency & Besźmarques & Unspecified \\
\hline Economy & Depressed & Buoyant \\
\hline Fashion & 'Staid, drab cuts and colours' (21) & $\begin{array}{l}\text { Brighter colours (190); and fewer } \\
\text { Goths (180) }\end{array}$ \\
\hline International investors & Canada, UK, USA & $\begin{array}{l}\text { Canada, but subject to a US blockade } \\
\text { (88) }\end{array}$ \\
\hline Language & $\begin{array}{l}\text { Besź (34 letter alphabet, unpatriotically } \\
\text { compared to Cyrillic) }\end{array}$ & $\begin{array}{l}\text { Illitan (Roman script since 1923, prior } \\
\text { to that Arabic-Sanskrit hybrid) }\end{array}$ \\
\hline Outlook & Pessimism (193) & (Inferred) Optimism (193) \\
\hline Political regime & (Historically) Monarchy & $\begin{array}{l}\text { One party regime 'People's National } \\
\text { Party.' }\end{array}$ \\
\hline Religion(s) & Besźel Orthodox, Judaism, Islam & Secular \\
\hline $\begin{array}{l}\text { Stereotypical culinary } \\
\text { ingredient }\end{array}$ & Potatoes (235) & Spices (235) \\
\hline Time-keeping & (Inferred) Punctuality (193) & Tardiness (193) \\
\hline
\end{tabular}

Table 1: Selected current characteristic traits of Besźel and Ul Qoma 
The extent of difference suggests independent development and indeed Besźel and U1 Qoma exist in a state of chronic cultural separation despite their extreme physical proximity. This is a tale of two cities between which unpoliced contact is forbidden: while residents of each city learn about the other's history, geography, politics, and see it in photographs and news footage, any direct contact requires a series of protocols, some of which might seem reasonable, or familiar: entry permits; international mail; international dialling codes; intercultural training courses. What complicates these apparently banal measures is the relative positioning of the cities, each one around, within, amidst the other. The two populations live side by side, but under a regime that requires ostentatious and systematic disregard or 'unnoticing' (14) of the other in any but a tightly regulated set of encounters: citizens of one city must not sense (see, smell, hear, touch) the other city that weaves through their own. ${ }^{2}$ The building two doors down, 'grosstopically' speaking, but in the other city, goes up in flames? Watch the breaking international news story on television, by the light of the fire, but do not, on pain of swift and definitive disappearance by the mysterious Breach, be seen to take a direct glance (81). Your best lead on your murder inquiry comes via an international call from the other city, from someone who has seen your appeals for information posted only in your own city, and not in his? Until you report it, this makes you accessory to the crime of seeing across the invisible inter-city boundaries, and you will spend a sleepless night with red wine and your recording of Van Morrison's 1987 tour of Besźel trying to master your excruciating anxiety (40-45). Light and the shadows of unseen buildings fall across; breezes, and, more problematically, litter, blow across the intercity division (shadows 29, 162; reflections 31; light 46; litter 80). But the good citizens of Besźel and U1 Qoma will not follow nature's example or give in to primal cognitive impulses to smell their international neighbours' cooking or to hear the sounds drifting from the other city.

For most inhabitants of Besźel and U1 Qoma - as opposed to readers of the book- the question is this one thing or two? is never even put: the separation of the cities is absolute, unquestioned, a fundamental principle of life. Indeed, it is taken as inaccurate

\footnotetext{
2 Note that the terms are 'unseeing' and 'unhearing,' rather than 'unlooking' or 'unlistening.' To 'unnotice' is to not-perceive, and while 'un' may indicate 'undoing' an inadvertent perception, the preferred behaviour is not to notice the other in the first place (see also Marks 2013: 222-223; Martin 2013: 713). Note also that what must not be directly perceived is the other city and anything within it. However, inhabitants who cross from one city to the other according to proper procedures are perfectly visible in the city of arrival (albeit no longer so at home).
} 
and insulting to align Besźel and U1 Qoma with, say, Berlin or Jerusalem. The application from Inspector Tyador Borlú of Besźel's Extreme Crime Squad, our detective-narrator, to attend an international conference 'Policing Split Cities' —with sessions on Budapest, Berlin and Jerusalem (90) — came perilously close to being refused. To a colleague shocked by his approved participation he recounts: 'My super said it wasn't just a misunderstanding of our status it was an insult to Besźel ... I did at least meet my first Ul Qomans, who'd obviously managed to overcome their outrage, too' (91). In Besźel and U1 Qoma, only the banned extremist grouplets of unificationists or far-right nationalists contest this reading of the cities as separate: believers in some version of a 'God-, destiny-, history-, or people-intended unity' (52), for the police they are kooks (48) and nutters (53) all.

Yet the minority unificationist opinion, wherein the separation deplorably defies rightful unity, underpins numerous publicly available readings of the novel. That is, critical and popular receptions of The City and The City, which range from a parable of the evils of segregation to calls for interdisciplinarity (see below), fundamentally buy into the unificationist position: this is one city — that is, one population, divorced - and that divorce is (variously) unhelpful, misguided or founded on injustice.

The resonances with real-life split cities seem inevitable, and references to them (or to discrimination on political affiliation, race or financial standing) proliferate in discussion of the novel across various genres. (A small but indicative sample includes Bairner 2012: 7, 14; Duggan 2013; Farrell 2011 and the related discussion on the blog page 'The City and The City' on Out of the Crooked Timber; Wagner 2009; the interview with Miéville 'Unsolving the City'). Indeed, the paratextual presence of Miéville's own activism, his academic publications on Marxism, his critical writing on politics and 'fantasy' (Miéville 2002) and the rewarding political readings of his other novels (Freedman 2003, 2005; Birns 2009; Bould 2009; Burling 2009; Coley \& Lockwood 2012; Cooper 2009; Kendrick 2009; Palmer 2009; Rankin 2009; Sanders 2009; Vint 2009a, 2009b; Ganapathiraju 2012) ${ }^{3}$ encourage political interpretations of The City and The City, which seen in these terms must be an allegory of social injustice. It is not surprising, therefore, to find the novel used, in turn, as a template for reading Miéville's social criticism, such as when blogger Cory Doctorow, reacting to Miéville's

\footnotetext{
${ }^{3}$ The 2009 papers are from the special issue of Extrapolation on Miéville's fiction.
} 
(2012) piece in the New York Times denouncing inequalities in contemporary London, references the book by entitling his post 'China Miéville's London: the (authentic) city and the (banks and surveillance) city' (Doctorow 2012). The city is, or should be, one.

The appeal of the unificationist reading is not confined to the political: Geoffrey Crossick, speaking at a Knowledges Futures conference in 2009, deploys the recentlyread novel in his closing plea for collaboration between STEM (Science, Technology, Engineering and Mathematics) and the disciplines of the Arts and Humanities. Having described the book as presenting two separate cities inhabiting the same space and 'unseeing' each other, he argues that STEM and the Arts and Humanities exhibit the same behaviour in relation to each other and concludes:

We're part of a single intellectual landscape, albeit a subtly differentiated one. My lesson from the issues I've been outlining today, $[. .$.$] is that we're not two cities but one. We must acknowledge$ that the city is one, that academic disciplines occupy the same broad territory. In other words, we should stop unseeing each other. (Crossick 2009:14; our emphasis)

De Groot, reviewing scholarly books on historical re-enactments for Rethinking History, although finding in The City and The City 'a clear echo of ... the Israel-Palestine situation' (2011: 591) also uses it to represent the crosshatched co-presence of the past and the present, the latter of which tends to ignore the former, to its disadvantage.

For the above commentators, despite their varying frames of reference, the two cities should add up to one. Yet there is an alternative arithmetic, one strongly suggested in the book, whereby the addition of the two cities must yield a third. Influential theoretical approaches to third spaces / places, whether founded in notions of hybridity (Bhabha 2004), intercultural education (Kramsch 1993) or translation theory (Pym 2002), suggest that where there are two cultures in relation to each other, we look for a third, between them; or indeed, actively strive to build it ourselves in the interstices of the cultures in question. ${ }^{4}$ What these approaches share is the presupposition of some degree of irreducible alterity ${ }^{5}$ and the need to find a pragmatic solution to the problems that this poses, at the level of the individual or of professional practice, solutions that work with and between difference, rather than aiming at its eradication. These models have yielded varying representations of intercultural agents, whether they emphasise the

\footnotetext{
${ }^{4}$ We borrow 'Striving for the third place' from Lo Bianco, Crozet and Liddicoat (1999).

5 'Irreducible alterity' is from Venezia's discussion of 'Weird fiction' as practised by Miévielle (Venezia 2010: para. 3).
} 
enriching of the individual or his/her potential role as go-between or mediator. While these models accept the existence of cultural difference, they also (and in contradistinction to, say, earlier models prevalent in language teaching encouraging emulation of a native speaker) imply mixity: border-crossing, straddling of borders, porosity, positioning of individuals with respect to other cultures - these become privileged tropes. The heroic figure of these discourses, the intercultural agent, would operate where cultures meet, building meaning out of that encounter, and a home in the interstices, rather than falling through the gaps.

While Kramsch's Third Place has not been without its critics (see de Nooy 1996: 214), the concept has had enormous influence and tenacity in language and culture education. Kramsch herself has elliptically signalled that it is time to re-evaluate the analytical power of Third Places, repackaging placehood as symbolic competence in navigating the construction of meaning through discourse (2011:355). It is our contention that whereas Kramsch is elliptical, Miéville's novel, read in response to intercultural questions, lavishly stages the needed re-evaluation of Third Places.

Our reading of The City and The City therefore sets itself the task of locating portrayals of border-crossing; of intercultural agency positioning the individual with respect to the 'foreign'; of mixity between the two cities; and of possible configurations of a third place. This interest in thirdness is shared by certain of the protagonists for whom the radical disjuncture of the two cities is intolerable. If for some the barrier between the cities, tantalizingly described as skin or membrane (see 'Third places' below), must be excised (unificationists); expanded to envelope and colonize the other (nationalists); for others it should be pulled aside to reveal a third space, and a third city.

An interpretative framework of cross-/intercultural studies allows us to take seriously the detailed construction of difference between Besźel and Ul Qoma, and of the system for maintaining their separation. It also makes clear that the cultural distinctiveness of each city is never seriously challenged in the novel, the plot of which is not about breaking down barriers to allow the (re)unification of a population torn apart. Indeed, when the hero-protagonist's journey leads him to a point of decision between challenging or enforcing the established order of cultural separation, his ultimate choice between 'two nonchoices' is 'not to uphold the law, or another law, but to maintain the skin that keeps law in place. Two laws in two places, in fact' (373). That choice- to 
keep the cities apart-is, in our reading, the rejection of intercultural agency. It also crystallises the limits of the concept of third space, in ways our analysis will spell out.

\section{Crossing}

Although separated, the cities are not hermetically sealed, neither to the outside world nor with respect to each other: physical movement from one to the other is possible, under tightly legislated conditions and preceded by intensive training. ${ }^{6}$ An examination of the training, its methods and desired results, allows us to ask whether these border crossers are equipped with anything resembling intercultural agency.

As stated above, prevalent discourses of language and culture teaching privilege the development of the intercultural agent, endowed with skills of critical literacy and meaning-building, as well as attitudes of respect, tolerance and openness:

$[\mathrm{R}]$ eflection ... has led to the recognition that it is neither appropriate nor desirable for learners to model themselves on native speakers with respect to the learning about and acquiring an understanding of another culture.

We have therefore introduced the concept of the 'intercultural speaker,' someone who has an ability to interact with 'others,' to accept other perspectives and perceptions of the world, to mediate between different perspectives, to be conscious of their evaluation of difference ... (Byram, Nichols \& Stevens 2001:5)

The metaphor of seeing used here, implied by 'perspective' and 'perception,' will be recognized as a current commonplace in talk about language teaching, cultural contact, internationalization of the curriculum, and the encouragement of exchange experiences, all of which swarm with references to 'expanding horizons,' 'viewing the world differently' and 'seeing the world through new eyes.'

Seeing the world differently is of course the outcome of successful 'intercultural' training in Besźel and Ul Qoma, but here the meaning is quite literal. Although all spontaneous sensation of the other city is forbidden, instruction is presented as primarily concerned with the skills of seeing and unseeing. Borlú explains the course from which the murder victim's American parents have been exempted:

\footnotetext{
Had the Gearys been regular tourists, they would have had to undergo mandatory training and passed the not-unstringent entrance exam, both its theoretical and practical-role-play elements, to qualify for their visas. They would know, at least in outline, key signifiers of architecture, clothing, alphabet and manner, outlaw colours and gestures, obligatory details—and, depending on their
}

\footnotetext{
${ }^{6}$ The cities host international celebrities and trade delegations, they take in refugees, Ul Qoma has a significant international student population engaged in archaeological digs, and there are even tourists.
} 
Besź teacher, the supposed distinctions in national physiognomies — distinguishing Besźel and Ul Qoma, and their citizens. They would know a tiny bit (not that we locals knew much more) about Breach. Crucially, they would know enough to avoid obvious breaches of their own. (93).

In addition to the information on Breach, clearly included as deterrent to noncompliance, the training centres on the visual signifiers of cultural identity which should trigger the appropriate cognitive response. In terms of course outcomes, it should be noted that tourists are not expected to acquire a native mindset — but to behave as if they have.
After a two-week or however-long-it-was course, no one thought visitors would have metabolized the deep prediscursive instinct for our borders that Besź and U1 Qomans have, to have picked up real rudiments of unseeing. But we did insist that they acted as if they did. We, and the authorities of Ul Qoma, expected strict decorum, interacting with, and indeed obviously noticing, our crosshatched neighbouring city-state not at all. (93)

[A]s long as they do not point and coo [across the border] everyone concerned can indulge the possibility that there is no breach. It is that restraint that the pre-visa training teaches, rather than a local's rigorous unseeing, and most students have the nous to understand that. (94)

Thus, the prime pragmatic objective is to ensure outsiders maintain the separation of cultures, through a form of respect or 'politeness' (225), which implies a simulation of local behaviour, but not the adoption of the value system.

When Borlú must cross the border to pursue his inquiry, more is expected of him, as a native inhabitant of one of the cities. His preceding trip to Ul Qoma lies well in the past and his previous test results, on which depends the delivery of his visa, have expired. In light of this, and the urgency of the criminal investigation, he undergoes an accelerated, two-day programme giving him the opportunity to experience the latest teaching and learning methods for 'acclimatization pedagogy' (160). The blended approach combines face-to-face native-speaker delivered instruction, in Illitan immersion mode, and CALL. The latter uses a simulator manipulating images so that Besź buildings, initially visible, as they would be for the Besź in Besźel are gradually underlit, move out of focus, while their previously unseeable Ul Qoman neighbours become the highlighted focal points. That is, while the course covers language competency, cultural knowledge (knowledge about history, geography, law) the goal is again that of appropriate seeing, although wrapped up in some concern for the psychological welfare of border-crossers: 'Mostly ... the course was concerned to help a Besź citizen through the potentially traumatic fact of actually being in U1 Qoma, unseeing all their familiar environs, where we lived the rest of our life, and seeing the buildings beside us that we had spent decades making 
sure not to notice' (161). In line with the goal of practical competence, assessment, efficiently delivered via computer, requires discrimination between Besź and Ul Qoman artefacts (lorries, temples, citizens) (161); that is, it tests the student's ability to un/see appropriately. This is training, then, which may indeed encourage 'acceptance of other perspectives,' but through a process of substitution, rather than addition, swapping one set of eyes for another. The Ul Qoman view is substituted for the Besź, or vice versa. There is no encouragement to re-evaluate, to 'mediate between perspectives' (Byram et al. 2001: 5): rather all energies are directed at shifting visual frames of reference without jeopardizing one's monocular vision and thereby compromising the system of cultural separation.

For a further example of the tenacity of this separation, we turn to a possibly transgressive crossing, that of Canadian academic and long-term U1 Qoman resident, David Bowden. Towards the end of the book, he nearly achieves a getaway of spectacular cheek, a striking example of the cultural outsider working the rules for personal gain. He appears indeed to come close to the ideal of the intercultural agent as described above, or as portrayed by Kramsch when she suggests that interculturality 'is in fact a process of positioning the self both inside and outside the discourse of others' (2011: 359).

Not for Bowden the rooftop helicopter extraction of other conspirators. ${ }^{7}$ Rather, his plan is simply to walk out of the cities, in what would be plain sight of the authorities, if only those authorities could determine that they were permitted to see him. Under cover of civil unrest, Bowden gets himself to the cities' version of Checkpoint Charlie, but it is unclear whether he passes through it from Ul Qoma to Besźel and therefore, in which city he is located as he moves away from the crossing point. Bowden adopts an ambiguous gait and moreover a route through crosshatched terrain which leave possible witnesses and pursuers unsure as to whether he is legally visible. However Borlú has by this stage been empowered to see.

Bowden was instantly visible. That gait. Strange, impossible. Not properly describable, but to anyone used to the physical vernacular of Besźel and Ul Qoma, it was rootless and untethered, purposeful and without a country. I saw him from behind. He did not drift but strode with pathological neutrality away from the cities' centres, ultimately to borders and the mountains and out to the rest of the continent. (353)

\footnotetext{
${ }^{7}$ Or indeed the realization of his youthful prediction of a disappearance into Orciny (180); see later section on this additional city.
} 
Here he is then, an apparent intercultural hero, on the move, manipulating cultural signifiers for his own ends; and, while this is normally impossible in the cities, fluid in his cultural identification. But one places oneself outside others' discourses (see Kramsch above) at one's peril. Borlú and Bowden face off.

\footnotetext{
Bowden had still not committed to where he was. I said, "Which city are you in?" ...

"Either," he said.

So I grabbed him by the scruff, turned him, marched him away. Under the authority I'd been granted, I dragged Breach with me, enveloped him in it, pulled him out of either town and into neither, into the Breach. (362-363)
}

Bowden's 'either' in a flash becomes 'neither.' His claim that his positioning is up for negotiation, that it might even be his own choice rather than a matter of checkpoints and passes, demonstrates unacceptable cultural free-thinking. On the other hand, in suggesting that he is in either one place or the other, Bowden's discourse is consistent with that of the cities: it does not suggest a double or shared identification. Utterly reliant on it for the success of his plan to escape unseen, he maintains the separation between the cities.

\section{Third places}

But surely, but surely, this separation cannot be effectively maintained? Our doubts have nothing to do with the abilities of the fictional inhabitants of two imaginary cities to control their sensory perceptions, but rather arise from that accumulation of work around hybridity and third spaces alluded to earlier. Admittedly, in terms of literal, physical space, Borlú's narration repeatedly emphasizes that the cities touch and entwine, adhere to and partially overlay each other. His favoured metaphors for the division between them emphasise closeness: separated by membrane $(282,303)$, or skin (372) the cities offer no intervening space. But Borlú's voice is that of a child of one of the cities. Should we not expect that a narrative which in many ways has shown itself aware of current discourses about cultural difference make room for a third place, and might such a space not be a place of hybridity or intercultural contact? ${ }^{8}$ Indeed, various candidates for third spaces arise in the novel, in different disciplinary or generic contexts. The question is whether they support an interpretation of the novel validating thirdness as a form of intercultural agency; or whether third space is revealed as the

\footnotetext{
${ }^{8}$ See the book's refusal of essentialism, its acknowledgment of both the evolution of cultural practices and of how a culture understands the notion of culture itself (for example, 161).
} 
very underpinning of the radical separateness of Besźel and Ul Qoma and thus a denial of interculturality.

\section{Copula Hall}

The first context is the administrative one, which arguably does produce a physical, identifiable, in-between space: this is Copula Hall, the building which bears the same name in both cities and where they meet administratively 'at a juncture, an interstice, one sort of border built above another' (72). If externally the Hall belongs in both cities, within it is more complicated: 'internally much of it is in both or neither' ( 72 , our emphasis, see also 157). Not only does it have a physical presence, but a function which potentially aligns it with Pym's intercultures (2002) which, for his discussion, he restricts to professional contexts. Our detective first takes his narratees to Copula Hall for a meeting of the Oversight Committee as he attempts to refer his murder case upwards: it appears that the victim was killed in one city and illegally dumped in the other, producing a breach of the cities' separation. Investigation of such a crime transcends his own authority, and belongs to Breach alone.

But the hope of an interculture, a space which would be shared (in the style of a DöplirCaffé) or located beyond the cities is swiftly dashed: this third space, an administrative expedient, cannot sustain life. While the 'neither' spaces, which exist in Copula Hall only, do have their government, the Oversight Committee $(158)^{9}$, there is no sense of a shared culture and ' $[t]$ he hall feels not collaborative but empty' (83). This lack of (inter)cultural viability is further demonstrated in the Hall's aesthetics:

The corridors of Copula Hall are in a determined style that must have evolved over the many centuries of the building's existence and centrality to Besź and Ul Qoman life and politics: they are antique and haute, but somehow vague, definitionless. The oil paintings are well executed but as if without antecedent, bloodlessly general. (83)

This is a style which, despite its particularity and history, somehow presents itself as having neither of these characteristics. The lack of definition of the corridors, the paintings (exsanguinated, lifeless, defying interpretation), are, we might say, as though without genre and therefore impossible to interpret. Compare this description with that of the contents of the corridors' display cabinets: artefacts from the cities' pre-history,

\footnotetext{
9 'Its inside was complicated - corridors might start mostly total, ... become progressively crosshatched along their length, with rooms in one or other city among them, and numbers also of those strange rooms and areas that were in neither or both cities, that were in Copula Hall only and of which the oversight committee and its bodies were the only government' (157-158).
} 
their meaning is also undetermined. However, in contrast to the paintings, this is not because of their generality, but rather their evident specificity to an unknown genre. 'They are specific but opaque. I glanced at some as I left: a sag-breasted Venus with a ridge where gears or a level might sit; a crude metal wasp discoloured by centuries; a basalt die. Below each one a caption offered guesses' (83).

The impossibility of life between cultures is further insisted upon in the descriptions of the Hall's undercroft, which houses the point of official passage from one city to the other. Borlú's attempt to pass on his inquiry having been thwarted by the dubiously fortuitous discovery of CCTV footage showing the legal border-crossing of the van used to transport the murder victim's body; it having been decided, that is, that what has been committed is the lesser crime of murder, rather than breach, he must pursue his investigations internationally and so effects an officially sanctioned crossing into U1 Qoma: 'Beyond the Besź gates, below the main mass of Copula Hall, a no-man’s-land. The tarmac was unpainted: this was neither a Besź nor an Ul Qoman thoroughfare, so what system of road markings would be used?' (158). ${ }^{10}$ This impossible space, untamed by road-markings, this neither and therefore no-place (157), is described here and elsewhere as a no-man's-land: it is not a habitable meeting ground. Later, indeed, it will be a place of violence and death. It is of course logical that Copula Hall, a place which exists in order to regulate separation, should neither breed hybridity nor celebrate togetherness.

\section{Dissensi}

A second kind of interstitial space is also produced as an administrative necessity: dissensi is the collective noun for places of which the location is disputed: each city claims them and pending an accepted judicial outcome, unless the cities accept to class them as crosshatched, these spaces are neither. They are therefore officially uninhabited, culturally undetermined, and would be without interest for our study but for the fact that, with their suggestion that the cities' borders evade complete control, and when reinterpreted through non-administrative lenses, they contribute to various fantasies, principal amongst which is our next contender for thirdness, Orciny.

\footnotetext{
${ }^{10}$ For further use of 'no-man's-land' see page 277, where the same place is described as 'the yawning interstitial space.' On page 276 we learn that 'homeless men and women' congregate here: this is not a place of belonging.
} 
Orciny

Orciny is - and the interculturalist might sense impending fulfilment - ' $\mathrm{t}$ ] he third place. Between the city and the city' (247). But does Orciny truly exist? If it did it would be a very inconvenient truth and for much of the book the protagonists defuse the potential danger of Orciny with reassuringly benign generic labels. In Chapter 5 Borlú and his Besź sidekick Corwi have followed the trail of their murder victim, an American undertaking doctoral studies in U1 Qoma, to the headquarters of a group of Besź Unificationists. Mahalia Geary was, we learn, interested in '[o]ld wives' tales, rumours, urban myths, craziness' (60), the content of which is shortly clarified by one of the Unificationists: 'Orciny.' The unificationist informant, member of a fringe group and therefore under scrutiny, is agonizingly careful to give Orciny no political credence.

[Orciny] was a fairy tale. ${ }^{11}$ That was what he said.

“'Orciny's the third city. It's between the other two. It's in the dissensi, disputed zones, places that Besźel thinks are U1 Qoma's and U1 Qoma Besźel's. When the old commune split, it didn’t split into two, it split into three. Orincy's the secret city. It runs things." $(61)^{12}$

Borlú adds further explanation for the reader:

[A]s if the two crosshatched countries were insufficient, bards invented the third, the pretendexisting Orciny ... A community of imaginary overlords, exiles perhaps, in most stories machinating and making things so, ruling with a subtle and absolute grip. Orciny was where the Illuminati lived. That sort of thing. Some decades previously there would have been no need for explanations - Orciny stories had been childrens' standards, alongside the tribulations of "King Shavil and the Sea-Monster that Came to Harbour." Harry Potter and Power Rangers are more popular now and few children know those older fables. (62)

The problem, the danger represented by Mahalia, was that of not treating these tales as fantastical, of not dealing with them as a folklorist (62) but rather attending to them as fact.

Another sphere in which the status - generic or disciplinary — of Orciny must be clearly, firmly, stated is that of academia. Mahalia Geary had attracted a certain notoriety at a conference in Besźel, before the timeframe of the book, making brashly inappropriate claims about Orciny's existence. Having been told by Geary's grieving parents that their daughter's doctorate was on Orciny, Borlú attempts to verify this with her Canadianborn U1 Qoma-based supervisor:

\footnotetext{
${ }^{11}$ Corwi later uses 'fairy tale' to explain the status of Orciny to Geary's parents.

12 The speaker's assumption of an original singular city is far from proved, but of course is fundamental to his unificationist viewpoint.
} 


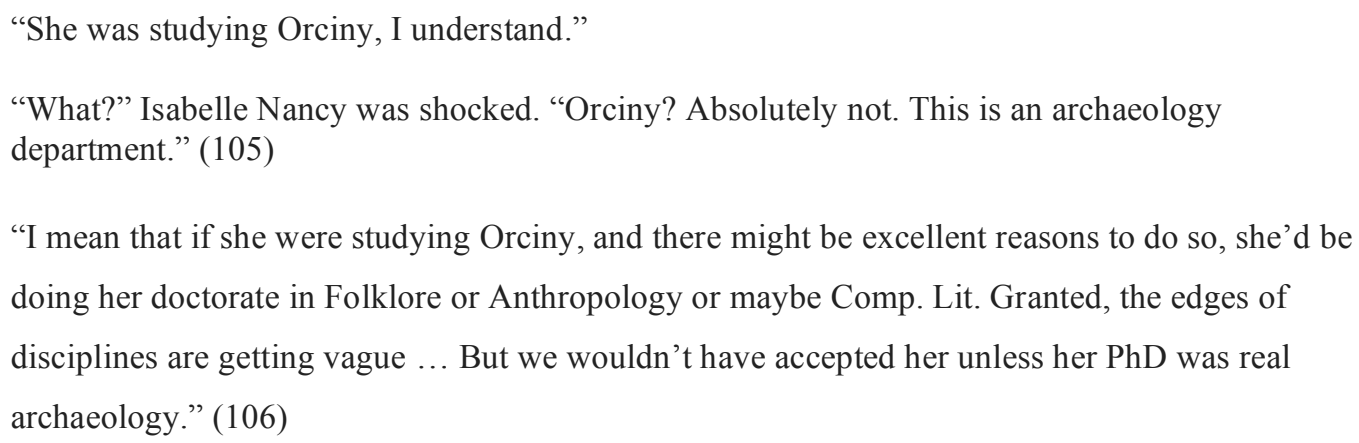

The calamity of disciplinary breach is demonstrated by Nancy's part-time colleague, David Bowden (see above), who inadvertently committed professional suicide with a youthfully psychedelic work, the provocatively entitled Between The City and The City, the thesis of which is that Orciny's existence can be proved. For all that he has publicly recanted, for all that the book is banned in the two cities, his career has been blighted by its claims that Orciny is a secret colony whose inhabitants live amongst those of U1 Qoma and Besźel, unseen.

What then is Borlú to do when clues accumulate to suggest that Orciny is not (merely) the stuff of folktales, but a malign force of possibly supernatural powers which has intruded into his life to produce first a murder and then its cover up? Does he need to change his frame of reference?

The same question arises for readers: by the conventions of which genre should Orciny be read? Certainly the book opens in grittily-familiar realist crime-story territory: a grey dawn, a weed-infested waste-ground, a young woman's body hidden under a discarded mattress. The corpse is examined, bystanders are interrogated, notes are taken, empirical evidence is compiled. Yet at the close of this generically comforting scene, reader expectations are complicated by our first encounter with Unseeing as Borlú lets his gaze wander down a nearby street before realizing that it has gone too far, has strayed into another country and must be recalibrated: 'When after some seconds I looked back up, unnoticing the old woman stepping heavily away, I looked carefully instead of at her in her foreign street at the facades of the nearby and local GunterStrász' (14). Where exactly is this woman and how are these two streets not one and the same street? Is their separation mystical? Science fictional ${ }^{13}$ The careful reader may note Borlú's criticism of the local journalists chivvying him for details at the crime scene: 'What was troubling

\footnotetext{
${ }^{13}$ The City and The City was awarded the Arthur C. Clarke and the British Science Fiction Association prizes for best novel. It received the Hugo award for best science fiction or fantasy novel of 2010.
} 
was less the trend to sensation, nor even the irritating behaviour of the new press's young writers, but more their tendency to dutifully follow a script written before they were born' (13). Could Borlú's concern be covert advice for reading the story: unquestioningly following a script you recognise will not be helpful? Perhaps the rules of the procedural crime fiction with which we seem to have started are not to be slavishly obeyed? If we interpret the novel as part of the genre of 'New Weird' fiction' ${ }^{14}$ or, more specifically, in terms of Miéville's oeuvre, ${ }^{15}$ then dismissal of a secret city accessed by other-wordly portals may be too hasty a move. The London of Miéville's fiction, for example, is not one of rational topography: rather, it possesses living streets ('Reports of Certain Events in London') and a mirror image (Un Lun Dun), and it can reconfigure itself and communicate (Kraken).

It is Orciny then which apparently holds the potential to be both the most disruptive and the most satisfying interstitial element of the book. It is disruptive firstly in the world of the story because it undoes the understanding of how the cities operate and, as the fairytale infiltrates his investigation, it challenges Borlú's very concept of reality. This same intrusion disturbs our generic expectations of the story we are reading, even more than the concept of unseeing, explained in rational terms by Borlú. Yet simultaneously, Orciny tugs us toward multiple satisfying resolutions. The explanation of the murder as one committed to silence an over-eager researcher about to reveal Orciny's secrets would provide generic closure to the crime story even as the acknowledgment of the paranormal/ fantasy aspect to the cities would fulfil expectations of Miéville's fiction. And finally, the revelation of the existence of Orciny would unfold the map of the cities to expose that hidden panel interculturalists always knew was there. One city or two? Three, of course - except that Orciny is brushed aside as mythological, after all, leaving only one serious contender for the role of Third Space.

\section{Breach}

In the cities, the crime of detectably piercing the borders is so grave, so terrible, and prosecution so unavoidably entailed, that there is one word for both: breach is the crime and Breach is the force unleashed to deal with it. 'Force' is deliberately ambiguous

\footnotetext{
14 The novel also won a World Fantasy Award and a Locus Award for best fantasy novel.

${ }^{15}$ This is clearly the invitation of the new Macmillan editions and re-editions of Miéville's fiction: the graphic style of the cover art has been standardised and the author's name is in much larger print than the title. Miéville has become a name, that is to say, a commodity, with its own currency.
} 
here: different generic framings of Breach within the novel allow interpretations ranging from a supervening police force, to a foreign power, to something more akin to a supernatural influence.

The first reference to the nature of Breach is related by Borlú as a childhood memory: 'As kids we used to play Breach. It was never a game I much enjoyed, but I would take my turn creeping over chalked lines and chased by my friends, their faces in ghastly expressions, their hands crooked as claws' (46). The element of fantasy and horror is reinforced by later references_-Breach is 'spooky shit,' says Corwi (56) — but is never allowed to settle into an untroubled paradigm that would allow the reader to interpret it unambiguously through the lens of fantasy. The example of the children's game establishes Breach is a mystical, supernatural power, but framing its horror as the subject of children's games adds an implied, second degree genre statement, namely that it is frightening to children because they do not understand its true nature. The difficulty of defining Breach is further complicated by references that evoke science fiction, or dystopic fiction, or internationalist conspiracy. The use of 'powers' (55) is as polysemous as 'alien' - 'Breach is ... an alien power' (78) states a right-wing politician-yet the reader's imagination is held in check when the same politician protests about the bureaucratic dimension of Breach. '[W]e need to stop rubberstamping the ceding to the Breach of considerable authority' (79), he complains, reminding the reader of earth-bound debates about the spectre of the United Nations as a 'World Government.'

However, for all the generic uncertainty over what Breach might be, what holds true for most of the novel is that Breach is nowhere: its avatars step out of shadows, materialise out of nothing: 'The Breach was nothing. It is nothing. This is a commonplace; this is simple stuff. The Breach has no embassies, no army, no sights to see. The Breach has no currency. If you commit it, it will envelop you. Breach is void full of angry police' (297). Being nowhere and nothing, lacking definable characteristics, without signifiers of cultural status or locus, Breach therefore seems a poor contender for Third Place. It merely repairs the damage done during instances of breach — suturing the membrane between the cities (370), cauterising the wound (81), or in less metaphoric terms, seizing wrong-doers and removing them from the cities. For foreigners, this means deportation; for locals, disappearance. 
Yet - as we discover - it is indeed Breach which occupies and represents thirdness.

When Borlú breaches, firing a shot from one city into the other, he finds himself detained by real people, in real places_ostensibly in the dissensi, which house the third space inhabited by Breach's avatars. And when he is co-opted into the investigation of the circumstances of his own breach, allowed to leave the building for the outside world in the company of Ashil, an avatar of Breach, he learns how such agents move from this third space into the cities. Incantation? Interdimensional portals?

... I realised we must be in U1 Qoma: that was where our destination was ...

"You're hungry," Ashil said.

"I can wait." ... He took my arm and guided me, and I hesitated because there was no food in sight except, and I pulled against him a moment, there were dumpling stations and bread stalls, but they were in Besźel.

I tried to unsee them but there could be no uncertainty: that source of the smell I had been unsmelling was our destination. "Walk," he said, and he walked me through the membrane between cities; I lifted my foot in Ul Qoma, put it down again in Besźel, where breakfast was ...

Ashil paid with Besźmarques. He put the paper plate in my hand, walked me back across the road into the supermarket. It was in U1 Qoma. He bought a carton of orange juice, gave it to me.

I held the food and the drink. He walked me down the middle of the crosshatched road.

My sight seemed to untether as with a lurching Hitchcock shot, some trickery of dolly and depth of field, so the street lengthened and its focus changed. Everything I had been unseeing now jostled into sudden close-up ...

"Where are you?” Ashil said. He spoke so only I could hear.

"I ..."

"Are you in Besźel or U1 Qoma?"

“... Neither, I'm in Breach.”

"You're with me here ... You're not in neither: you're in both."

He tapped my chest. "Breathe.” (303-304)

In many ways this is the counterpart to the scene of Bowden's failed escape, discussed above, but which comes later in the novel: there is the exceptional asking of the question 'which city?'; there is the attempt to comply with the discourses of the cities and to be in either one or the other. But as Ashil orders his food from one side of the crosshatched street and the other (recalling the freethinking patrons of the DöplirCaffé) Borlú starts to understand that his language is insufficient. In these cities of unseeing, perception is transformed before his speech: the city and the city have come together in 
stereoscopic vision, with all their sounds and smells, and Borlú still cannot utter the word that accounts for this, that he is in 'both.'

But how can Borlú and Ashil be standing in 'both' while tasked with maintaining the borders which make 'both' impossible? More subtle than the simple effrontery of ignoring boundaries, an act which would be visible and shocking to any citizen of either city, the skill possessed by the avatars of Breach is to pass unnoticed unless they choose to manifest in one city or the other: without Bowden's ostentation (368), they move with a gait, with gestures, with facial expressions, which bear the characteristics of neither city - and are thus invisible to all but one another. Manifesting is a mere matter of changing their behaviour in such a way as to become visible in either city (should they wish to appear to be Besź, or U1 Qoman), or in both (when they need to appear as Breach).

What Borlú discovers as he learns these skills and shifts into a different register of seeing, is that there is no going back from binocular to monocular vision. Moreover, it is for precisely this reason that breachers must be 'disappeared.' To breach once, 'for more than the shortest time ... you can't come back from that' (370). The separation of the cities, Borlú is told, depends crucially on the two populations respecting the division, and the law that maintains it. ${ }^{16}$ However, and by implication, to breach is to discover a way of seeing which cannot be unlearned: 'You'll never unsee again' (370). Were breachers allowed to continue living in the cities, the cultural contamination would eventually be such that the cities would begin to merge.

We end by reading the avatars of Breach as intercultural agents, of a sort. They are all former breachers, pressganged into service: 'None of us were born here. We were all once in one place or the other. All of us breached once.' (371) With an apparently perverse logic, it is precisely their capacity for breaching which makes them ideal candidates for keeping the cities apart. This third place that defines Breach, and which only Breach can inhabit, serves but one purpose: to be neither city. While it is true that the avatars of Breach can pass freely between the three spaces-Besźel, Ul Qoma and Dissensi - modifying their behaviour and visibility tactically as they do so, they must

\footnotetext{
${ }^{16}$ The power of Breach lies in nothing so much as its unquestioning acceptance by the populations of the two cities. These limits are exposed as such when the highly-placed US conspirators behind Mahalia Geary's murder shrug off an attempt by avatars of Breach to detain them.
} 
renounce their former lives and relationships. ${ }^{17}$ Intercultural agency, in this schismatic regime, comes at a price. Breach keeps the cities apart, and lives in neither-for all that Borlú, now an avatar of Breach, ends his narrative claiming, philosophically, to live 'in the city and the city' (373). Indeed - to labour a pun — since there are no Breach births, there is no possibility of interbreeding of the cities within this third space. Hybridity, genetic or cultural, is denied.

So too is genuine intercultural agency. If the function of this third place and its avataragents is to prevent hybridity between the two city-cultures and enforce their ongoing separation, it is by extension also to police the perceptual limitations of their citizens, and weed out those who demonstrate a budding ability intelligently to perceive, and move through, more than one culture at a time. That is, rather than intercultural agency becoming generalized throughout the population, those who demonstrate competence are cloistered in a special class. And that class, while it might be the repository of intercultural competence, in fact exists to keep cultures apart and therefore to deny interculturality.

\section{Conclusion}

We began this paper with the DöplirCaffe, where two cultures preserve what they value as their integrity (with room for individual takes on that), while yet interminglingworking with difference without abolishing it. We also saw that the answer to the question of whether such an establishment was one or two cafés depended on who was asking, the example given being that of the property tax inspector. This neatly illustrates the concept of generic stakes. Borlú does not simply mean that the interpretative framework of the tax inspector allows of only one answer to the question. Rather, within the genre of the property tax audit, there is an important pay-off attached to a particular answer. This then is the critical question: what is the pay-off of a particular reading; of any given generic uptake, in our case, a reading through the prism of intercultural theory ${ }^{18}$

\footnotetext{
${ }^{17}$ What keeps these pressganged avatars of Breach from simply returning to their former lives? When Ashil reveals that for many of his colleagues, the spectre of Orciny is not mere fantasy, but a lurking threat, we can read the myth of Orciny as a coercive force constraining the agents of Breach, just as much as respect for the invisible menace of Breach keeps the citizens of the cities in check.

${ }^{18}$ For another example, see pages 121-122 where Borlú ponders reading zoning laws to exclude the political head-quarters of extremists like the True Citizens from the residential area where they are currently located. The pay-off that is he clearly contemplating is not urban homogeneity but rather the convenient curtailment of their political activities.
} 
Intercultural theory, and its particular interest in third space(s), provides an interpretive purchase on Breach unavailable to readings solely exercised by questions of social equity, or the conformity of the novel to conventions of detective fiction, or indeed science fiction. The third place of intercultural theory suggests a map of the cities that draws attention to the space that separates them. It enables a forensic account of how the avatars of Breach move within, and between, the cities, modulating gait, gesture, facial expression and, who knows, the turn of a cuff or the tilt of a hat to become visible or invisible in one or both cities, at will. While even to the end the novel remains pleasingly haunted by unresolved questions, the location of Breach is not one of them. It is unambiguously Third-yet entirely defined by the power, and limitations, of thirdness. This is the flip side of our disciplinary pay-off: Breach can be read as more than a McGuffin; but as less than the third place that we might have hoped for.

So too has it been with the metaphor of the Third Place in language and culture teaching. It had, and rightly, such enthusiastic uptake because its promised benefit was to liberate learners from the burden of aping the native speaker, and to position those able to operate across cultures as wielding a privileged power. This empowerment is the equivalent of the 'Both' moment for Borlú, taught to see by Ashil in the middle of the crosshatched street. However, as Borlú also discovers, despite the promise of that moment, the Third Place is sterile, and has a vested interest in keeping cultures apart. ${ }^{19}$ We read this denial of productive intercultural competence as the danger, for language and culture teaching, of practice driven by the notion of 'place'; in particular, of practice which positions the learner within a cultural interstice that minimises the confrontation with irreducible difference. If the Third Place is a 'place-marker' (Kramsch 2011: 359), its power is as illusory as that of Breach.

\section{Acknowledgements}

Barbara Hanna's contribution to this paper was partially supported by a University of Queensland New Staff Grant and funding from the Faculty of Arts Assistant Deans' Article Development Scheme for 2012.

\footnotetext{
${ }^{19}$ In its role as wedge between cultures, Breach shares some of the characteristics of the citizens of Pym's intercultures, the professionals who through their work of translation, interpreting, diplomacy, make unnecessary (if not actively discouraging) the acquisition of any high level language or intercultural skills by anyone other than themselves (Pym 2002).
} 


\section{Reference list}

Bairner, A. 2012, 'Between flânerie and Fiction: Ways of Seeing Exclusion and Inclusion in the Ccontemporary City,' Leisure Studies, vol. 31: no. 1, 3-19. Online, available: doi: http://dx.doi.org/10.1080/02614367.2011.567358 [Accessed 19 January 2013].

Bhabha, H. K. 2004, The Location of Culture. Routledge, New York.

Birns, N. 2009, 'From Cacotopias to Railroads: Rebellion and the Shaping of the Normal in the Bas-Lag Universe,' Extrapolation, vol. 50, no. 2: 200-211. doi: http://dx.doi.org/10.3828/extr.2009.50.2.3

Bould, M. 2009, 'Mind the Gap: The Impertinent Predicates (and Subjects) of King Rat and Looking for Jake and Other Stories,' Extrapolation, vol. 50, no. 2: 307-325. doi: http://dx.doi.org/10.3828/extr.2009.50.2.10

Burling, W. J. 2009, 'Periodizing the Postmodern: China Miéville's Perdido Street Station and the Dynamics of Radical Fantasy,' Extrapolation, vol. 50, no. 2: 326-344. doi: http://dx.doi.org/10.3828/extr.2009.50.2.11

Byram, M., Nichols, A. \& Stevens, D. 2001, 'Introduction,' in Developing Intercultural Competence in Practice, (eds) N. Byram, N. \& D. Multilingual Matters, Clevedon, UK: 1-8.

Coley, R. \& Lockwood, D. 2012, 'The Radical Fantastic: Fabulatory Politics in China Miéville's Cities of "Lies-that-Truth,", C21 Literature: Journal of 21st-Century Writings, vol. 1, no.1: n. p.

Cooper, R. P. 2009, 'Building Worlds: Dialectical Materialism as Method in China Miéville's Bas-lag,' Extrapolation, vol. 50, no. 2: 212-223. doi: http://dx.doi.org/10.3828/extr.2009.50.2.4

Crossick, G. 'So Who Now Believes in the Transfer of Widgets?' Online, available: http://mars.gold.ac.uk/media/transfer-of-widgets.pdf [Accessed 19 January 2013].

de Groot, J. 2011, 'Affect and Empathy: Re-enactment and Performance as/in History.' Rethinking History: The Journal of Theory and Practice, vol. 15, no. 4, 598-599. Online, available: doi: http://dx.doi.org/10.1080/13642529.2011.603926 [Accessed 19 January 2013].

de Nooy, J. 1996, 'A Particularly General Phenomenon? Apropos of Claire Kramsch, Context and Culture in Language Teaching.' Australian Journal of French Studies, vol. 33, no. 2: 204-216. doi: http://dx.doi.org/10.3828/AJFS.33.2.204

Doctorow, C. 2012, 'China Miéville's London: The (Authentic) City and the (Banks and Surveillance) City,' Boingboing 4 March. Online, available: http://boingboing.net/2012/03/04/china-mievilleslondon-the.html [Accessed 19 January 2013].

Duggan, R. 2013, 'The Geopolitics of Inner Space in Contemporary British Fiction,' Textual Practice, vol. 27, no. 5: 899-920. doi: http://dx.doi.org/10.1080/0950236X.2012.751444

Farrell, H. 2011, 'Into the Breach: China Miéville's Other Reality,' Boston Review, March/April. Online, available: http://www.bostonreview.net/henry-farrell-china-mieville [Accessed 19 January 2012].

Freedman, C. 2003, 'Towards a Marxist Urban Sublime: Reading China Mieville's King Rat,' Extrapolation; vol. 44, no. 4: 395-408. doi: http://dx.doi.org/10.3828/extr.2003.44.4.03 2005, 'To the Perdido Street Station: The Representation of Revolution in China Miéville's Iron Council,' Extrapolation, vol. 46, no. 2: 235-248. doi: http://dx.doi.org/10.3828/extr.2005.46.2.5

Ganapathiraju, A. 2012, 'Urban Retro-futuristic Masculinities in China Miéville's Perdido Street Station,' The Journal of Popular Culture, vol. 45, no. 1: 3-14. doi: http://dx.doi.org/10.1111/j.15405931.2011.00907.x

Kendrick, C. 2009, 'Monster Realism and Uneven Development in China Miéville's The Scar,' Extrapolation, vol. 50, no. 2, 258-275. doi: http://dx.doi.org/10.3828/extr.2009.50.2.7

Kramsch, C. 1993, Context and Culture in Language Teaching. Oxford University Press, Oxford. 2011. 'The Symbolic Dimensions of the Intercultural,' Language Teaching, vol. 44, no. 3:, 354367. doi: http://dx.doi.org/10.1017/S0261444810000431

Marks, P. 2013, 'Monitoring the Unvisible: Seeing and Unseeing in China Miévielle's The City and The City, 'Surveillance and Society, vol. 11, no. 3: 222-236. Online, available: http://library.queensu.ca/ojs/index.php/surveillance-and-society/article/view/city\%26city [Accessed 19 December 2013].

Martin, N. 2013, 'Unacknowledged Cities: Modernity and Acknowledgment in China Miéville's The City and The City and Marc Isaac's All White in Barking,' European Journal of Cultural Studies, vol. 16, no. 6: 710-724. doi: http://dx.doi.org/10.1177/1367549413497692

Miéville, C. 2002, 'Editorial Introduction: Marxism and Fantasy,' Historical Materialism, vol. 10, no. 4: 39-49. doi: http://dx.doi.org/10.1163/15692060260474369 2004, 'Reports of Certain Events in London,' republished in Looking for Jake and Other Stories. Macmillan, London: 53-78. 2005, Looking for Jake and Other Stories. Macmillan, London. 2007, Un Lun Dun. Macmillan, London. 
2009, The City and The City. Pan Macmillan, London.

2010, Kraken. Macmillan, London.

2012, 'Oh, London, You Drama Queen' New York Times, 1 March. Online, available:

http://www.nytimes.com/2012/03/04/magazine/china-mieville-london.html? r=0 [Accessed 19 January 2013].

Lo Bianco, J., Liddicoat, A. J. \& Crozet, C. 1999, Striving for the Third Place: Intercultural Competence through Language Education. Language Australia, Melbourne.

Palmer, C. 2009, 'Saving the City in China Miéville's Bas-lag Novels,' Extrapolation, vol. 50, no. 2: 224-238. doi: http://dx.doi.org/10.3828/extr.2009.50.2.5

Pym, A. 2002, 'Intercultures and the Interface with National Cultures.' Online, available: http://usuaris.tinet.cat/apym/on-line/intercultures/intnation.pdf [Accessed 19 January 2013].

Rankin, S. 2009, 'AGASH AGASP AGAPE: The Weaver as Immanent Utopian Impulse in China Miéville's Perdido Street Station and Iron Council,' Extrapolation, vol. 50, no. 2: 239-257. doi: http://dx.doi.org/10.3828/extr.2009.50.2.6

Sanders, J. S. 2009, 'Reinventing Subjectivity: China Miéville's Un Lun Dun and the Child Reader,' Extrapolation, vol. 50, no. 2: 293-306. doi: http://dx.doi.org/10.3828/extr.2009.50.2.9

'The City and The City' 2011, Out of the Crooked Timber of Humanity No Straight Thing was Ever Made. Online, available: http://crookedtimber.org/2011/04/11/the-city-and-the-city/ [Accessed 18 January 2013].

'Unsolving the City: An Interview with China Miéville' 2011, Bldgblog. Online, available: http://bldgblog.blogspot.com.au/2011/03/unsolving-city-interview-with-china.html [Accessed 18 January 2013].

Venezia, T. 2010, 'Feature Interview: Weird Fiction: Dandelion Meets China Miéville,' Dandelion, vol. 1, no. 1. Online, available: http://dandelionjournal.org/index.php/dandelion/article/view/10/5 [Accessed 19 January 2013].

Vint, S. 2009a, 'Introduction: Special Issue on China Miéville,' Extrapolation, vol. 50, no. 2: 197-199. doi: $\mathrm{http}: / / \mathrm{dx}$. doi.org/10.3828/extr.2009.50.2.2 2009b, 'Possible Fictions: Blochian Hope in The Scar,' Extrapolation, vol. 50, no. 2: 276-292. doi: http://dx.doi.org/10.3828/extr.2009.50.2.8

Wagner, T. M. 2009, 'The City and The City' (Review), sfreviews.net. Online, available: http://www.sfreviews.net/mieville_city_and_city.html [Accessed 18 January 2013]. 